TAPROBANICA, ISSN 1800-427X. April, 2013. Vol. 05, No. 01: pp. 69-70, 2 pls.

(C) Taprobanica Private Limited, 146, Kendalanda, Homagama, Sri Lanka.

www.taprobanica.org

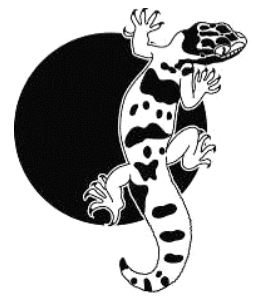

\section{Rediscovery of Ophiorrhiza radicans (Rubiaceae) from the southern Western Ghats, India}

As part of the collection and ex-situ conservation of the rare, endangered and threatened plants of the Southern Western Ghats, Ophiorrhiza radicans Gardner ex Thwaites (1859) was rediscovered from the Rosemala Estate of the Kollam District in Kerala after 119 years of its last record. The identity was confirmed by cross-matching the new collection with the type specimen (Sri Lanka, C.P. Thwaites 1706, K!) housed at Royal Botanic Gardens, Kew.

Ophiorrhiza radicans was originally collected by George Gardner in 1847 from an unknown locality in Sri Lanka and was published by George H. K. Thwaites (1859). In Sri Lanka, the species is known from the Kandy, Ratnapura and Kalutara Districts and all of them are represented by century old collections. Perusal of the herbarium specimens housed at National Herbarium, Peradeniya (PDA), filed under the name $O$. radicans, a collection by Dieter Mueller-Dombois and Nadarajah Balakrishnan in 1972 (72042306, PDA) from the Kudawa side of the Sinharaja Forests at an altitude of $1900 \mathrm{ft}$. elevation was noticed. In their field note on the specimen, it is mentioned as "....bark climbing herbaceous vine with small opposite leaves, nodal bracts or interpetiolate bract climbing on Dipterocarpus hispidus about $10 \mathrm{~m}$ up-trunk". Similar specimen were also collected by F. Klackenberg (Klackenberg 154B, US) from Sri Lanka. However, these two collections are entirely different from the rest of the collections and the paucity of adequate flowers and fruiting materials refrain us from confirming its identity, pending further studies in future.
In 1893, M. A. Lawson, an English botanist, collected Ophiorrhiza radicans from 'Colatoorpolay' (presently known as Kulathupuzha) in the Kollam District, Kerala, India. This is the only known collection from India. It has never been recollected even though Kerala and its adjoining area have been well explored in recent years; hence Deb \& Mondal (1997) treated the taxon in their "possibly extinct category'. Water \& Gillett (1998) also considered it in their Extinct (e.g., "Ex") category. It also appeared in many Red lists of India and Sri Lanka (ENVIS \& MOEF, 2003; MOE, 2012) and the present discovery is significant from a conservation point of view.

Quite unlike the Sri Lankan collections, the specimens from Kulathupuzha, India, are variable as these plants have a prostrate habit with shorter internodal length, and ovate or ovate-lanceolate leaves with rounded to shortly cuneate at base, etc. However, these features do not appear to warrant any separate taxonomic status, and are considered here to be an ecotype worth illustrating.

\section{Ophiorrhiza radicans Gardner ex Thwaites, 1859}

Enumeratio Plantarum Zeylaniae 139 (1859).

Herbs 10-30 $\mathrm{cm}$ long, rooting at the nodes; stems densely hairy, pale green, profusely branched. Leaves with pubescent petioles 0.6$1.5 \mathrm{~cm}$ and persistent, deltoid, pubescent stipules to $0.5 \mathrm{~mm}$ long; blades $1.5-4.5 \times 0.8-$ $2.5 \mathrm{~cm}$, ovate or ovate-lanceolate, acute at apex, rounded or shortly cuneate at base, entire or slightly undulate marginally, glabrous and dark green above, grayish and hairy along the nerves below; lateral nerves 4-6 pairs. Inflorescences terminal corymbose cymes, $0.5-2.5 \mathrm{~cm}$ across, few flowered, contracted, pubescent; peduncle 3-3.5 cm long, slender, pubescent; bracts and bracteoles similar, 0.5-1 $\mathrm{mm}$ long, narrowly triangular, caduceus. 
Hypanthium subglobose-obovoid, puberulous. Calyx lobes $0.5-0.7 \mathrm{~mm}$ long, subulate, acute, puberulous. Corolla white, $7-8 \mathrm{~mm}$ long, 6 $\mathrm{mm}$ in diam., infundibuliform, glabrous outside, villous at the middle of the tube, pubescent within; lobes $1.2-1.5$ x $1 \mathrm{~mm}$, ovate, slightly curved inward and acute at apex, shortly keeled at back. Stamens adnate to the base of the corolla or slightly above the middle, inserted; filaments $1 \mathrm{~mm}$ long; anthers $1 \mathrm{~mm}$ long. Ovary obovoid, $0.6-0.7 \mathrm{~mm}$ long; style 1-4 mm long, glabrous; stigma 2-lobed, lobes either lanceolate or capitates, glabrous or warty. Capsule 2 x $5 \mathrm{~mm}$, glabrous or slightly hairy. Seeds angular, glabrous, brown.

Specimen examined: TBGT 70442; Kallar, Thiruvananthapuram District, Kerala, India; E. S. Santhosh Kumar; 24 Sep 2012, TBGT 70442; Kulathupuzha, Kollam District, Kerala, India; S. Shailajakumari; 16 Jul 2012.

Flowering and fruiting: July-December

Habitat and ecology: This species is found in the forest floor of the evergreen and semievergreen forests at altitudes between 200-350 $\mathrm{m}$. In both localities, the plants are seen as scattered population of less than 50 individuals. The main associated species are Sonerila sahyadrica (Melastomataceae), Ophiorrhiza eriantha (Rubiaceae), Rungia sp.(Acanthaceae) and Rhynchotechum permolle (Gesneriaceae) etc.

Conservation: Since Ophiorrhiza radicans is a rediscovery after a long span of time, we have introduced the species to the field gene bank of Jawaharalal Nehru Tropical Botanic Garden and Research Institute, as part of their ex-situ conservation and for future studies.

Acknowledgements: The authors are grateful to the Director (JNTBGRI) for the facilities provided and to Subhani Ranasinghe (PDA) for providing the digital images of the specimens. Finally we would like to thank James L. Reveal (Cornell University - USA) for editing the manuscript.

\section{Literature Cited}

Deb, D. B. and D. C. Mondal, 1997. Taxonomic revision of the genus Ophiorrhiza L. (Rubiaceae) in Indian subcontinent. Bulletin of Botanical Survey of India, 39: 1-148.
ENVIS and MOEF, 2003. Red List of threatened vascular plants of India. ENVIS Centre, Botanical Survey of India, Howrah: 144.

MOE, 2012. The National Red List 2012 of Sri Lanka: Conservation status of the Fauna and Flora. Ministry of Environment, Colombo: viii+476.

Thwaites, G. H. K., 1859. Enumeratio Plantarum Zeylaniae - part 2: 139.

Walter, K. S. and H. J. Gillett (eds.), 1998. 1997 IUCN red list of threatened plants. Compiled by the World Conservation Monitoring Centre. IUCN, Gland, Switzerland and Cambridge, UK: 862.

Submitted: 19 Jan. 2013, Accepted: 08 Feb. 2013 Sectional Editor: James L. Reveal

\author{
E. S. Santhosh Kumar ${ }^{1,2}$, \\ S. Shailaja Kumari ${ }^{1} \&$ P. E. Roy ${ }^{1}$ \\ ${ }^{1}$ Jawaharlal Nehru Tropical Botanic Garden \& \\ Research Institute, \\ Palode, Kerala 695562, India \\ E-mail: santhoshkumares@ gmail.com ${ }^{2}$
}




\section{PLATE 9}

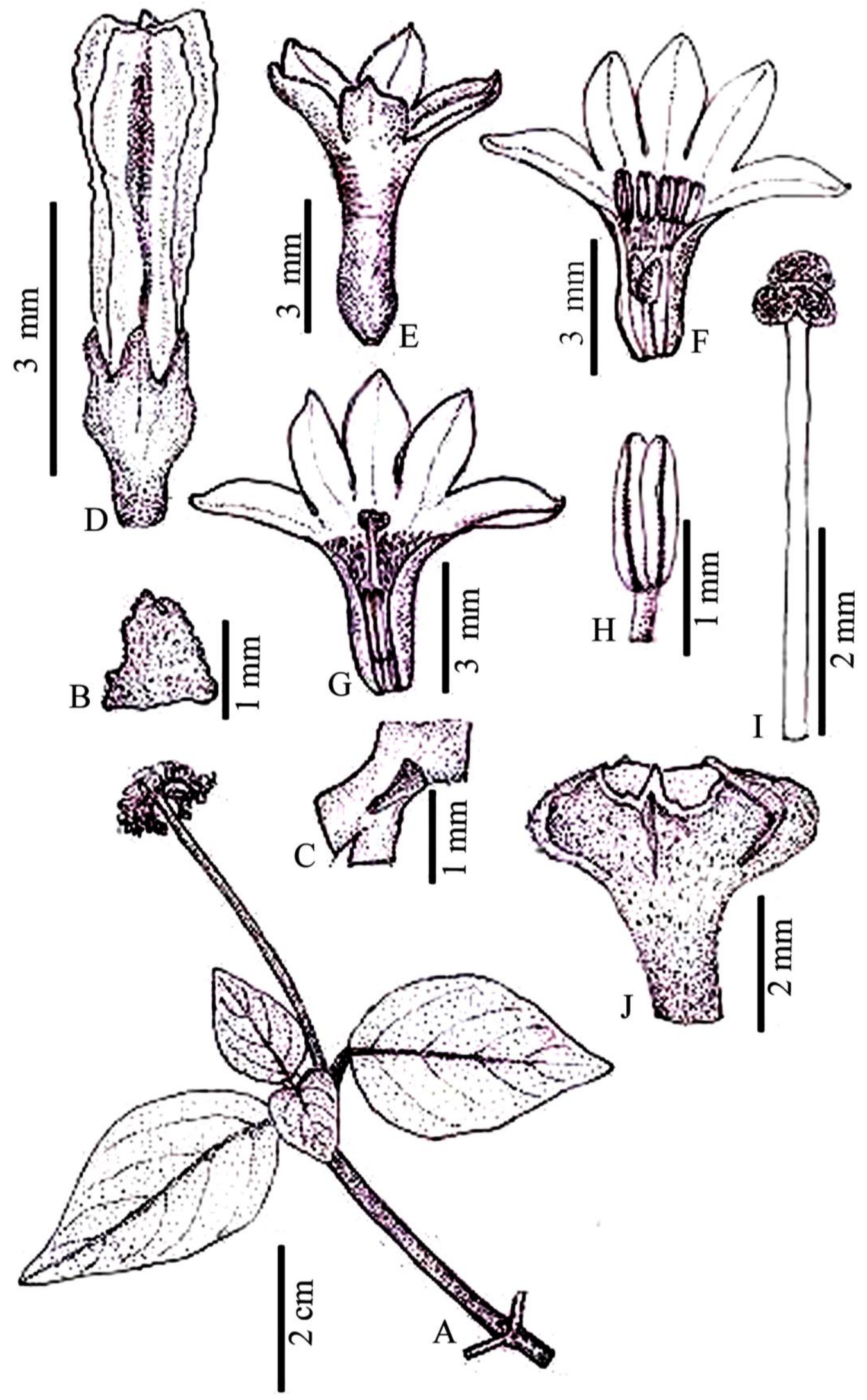

Figure 1: Ophiorrhiza radicans, A, Twig; B, Stipule; C, Bract; D, Flower bud; E, Corolla; F, Corolla split open (Short styled form); G, Corolla split open (Long styled form); H, Stamen; I, Style and stigma (Long styled form); J, Capsule. 


\section{PLATE 10}
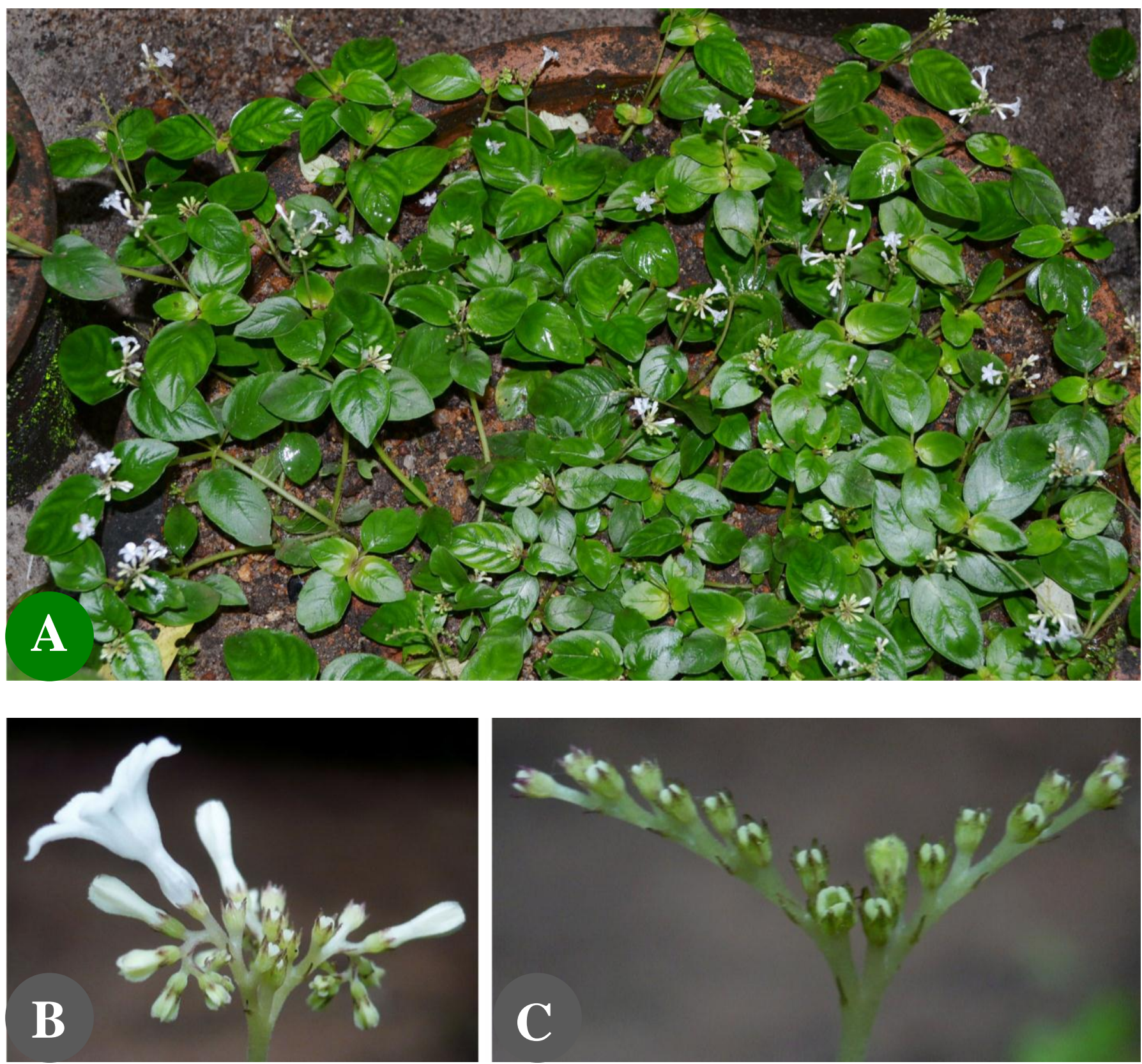

Figure 2: Ophiorrhiza radicans, A, Habit; B, Inflorescence; C, Fruits (Immature). 